\title{
Understanding the Influence of Electronic Word-of-Mouth on Outbound Tourists' Visit Intention
}

\author{
Ping Wang \\ Turku School of Economics, University of Turku, Turku, Finland \\ ping.wang@utu.fi
}

\begin{abstract}
The valence of online user-generated reviews is an increasing important antecedents affecting tourist's decision with the pervasion of Web 2.0 and information and communication technology. The purpose of this study is to explore the influence of electronic word-of-mouth (eWOM) on outbound tourists' intention to visit a destination through a dual-process perspective. A research model was proposed based on the dual-route theory of elaboration likelihood model (ELM) and theory of planned behavior (TPB). The research model was empirically tested with the data collected among the Chinese outbound tourists. The research results indicate that, tourist's attitude towards a destination was positively influenced by argument quality of eWOM, and intention to recommend the destination before travel was positively influenced by attitude towards destination and source credibility of destination related eWOM. Outbound tourists' intention to visit a destination was positively influenced by argument quality, attitude towards destination, and WOM intention. Several practical and theoretical implications are also discussed in the paper.
\end{abstract}

Keywords: Electronic word-of-mouth (eWOM), travel decision, online travel information, visit decision, elaboration likelihood model, theory of planned behavior

\section{$1 \quad$ Introduction}

With the advancement of information and communication technology (ICT) and advent of Web 2.0 in recent years, tourists are enabled to communicate virtually and share travel experience, reviews online [1]. Increasing amounts of user-generatedcontent (UGC) were spawned in the form of online travel experience or online reviews that pertain to personal experience with particular service or products which is also described as electronic word-of-mouth (eWOM) [2]. EWOM are available to a multitude of people via Internet and Web 2.0 platforms, which is likely to generate persuasive effects on target audiences, such as potential customers [3]. As an information-intensive industry, tourism was deeply influenced by eWOM [4-7]. Electronic word-of-mouth have facilitated travel information searching behavior, and influenced tourists' travel planning behavior [8, 9]. Tourists nowadays are increasingly using eWOM to inform themselves about travel-related services and products, for travel planning and travel related purchasing [10-12]. 
As eWOM has strongly affected tourism industry especially in tourist's decision making process, a considerable amount of literature has been focused on eWOM in tourism [13-16]. These studies mainly focused on two streams: one stream focused on exploring the factors influencing eWOM generating motivation [2, 9, 17], while the other stream concentrated on the impacts of eWOM on target behavior [18, 19]. Notwithstanding, our understanding about how eWOM influence tourists' visit intention is still scant. What is the most effective information influencing tourists' attitude towards destination, and furthermore their visit intention, and how? Thus, researches aiming at solving this puzzle are needed.

A structural model based on well-tested theories was proposed in this research to explore the influence process of eWOM on outbound tourists' intention to visit a destination. Empirical data was collected among Chinese outbound tourists via structural questionnaire survey. This study contributes to the understanding of how destination related electronic word-of-mouth impact outbound tourists' leisure travel destination decision-making with empirical evidence. Furthermore, the influence route before initial attitude formation toward a destination is also explored.

The remainder of this article is structured as follows: In section 2, theory of elaboration likelihood is introduced, and incorporated to the theory of planned behavior holding that behaviours are influenced by intentions, intentions by attitudes $[20,21]$. Nine hypotheses are proposed. Research method is delineated in section 3 , including data collection, descriptive analysis of the sample characters, and measurement model. In section four, structural equation model is used to analyse data with AMOS22.0. In section five, we give implications for both academic and practice. At the end of the paper in section six, limitations of current research and future research suggestions were discussed.

\section{Research Model and Hypotheses}

\subsection{Elaboration Likelihood Model}

Elaboration likelihood model (ELM) originates from social and consumer psychology, which suggests that attitude changes in two distinct routes: central route and peripheral cue [22]. The basic idea of ELM suggests that the way individuals are persuaded varies according to the extent to which they are willing to engage in elaboration of the persuasive issue. In the central route, individuals think more critically about issue-related arguments in an informational message and scrutinize the both pros and cons as related to those arguments prior to forming their target behavior [23]. In contrast, in peripheral route to attitude change, a relatively less cognitive effort is needed. A person may simply rely on cues related to target behavior, like prior users, prior related personal experience, and credibility. The central route is message-related argument oriented, while the peripheral route is process cues-oriented.

'Elaboration' is defined as 'the extent to which the individuals engage in information contained in the communication, and mentally modify or process the issue' [24]. The term 'likelihood' illustrates whether elaboration is likely or unlikely [24], and is used to describe individuals would add something of their own to a given information 
in a concrete communication $[22,23]$. In the context of current study, people in high likelihood of having an outbound travel are more likely to be persuaded by potential destination related electronic word-of-mouth through a central route, what's more, they think more critically about the destination related-message of eWOM. On the contrary, people in a low likelihood would refer to peripheral cues, such as the credibility of the information source. It is suggested that individuals' degree of elaboration forms a spectrum of message-related thinking, which could vary from little to high extent. What's more, the attitude change may happen at any extent of elaboration [23], that is, both central route and peripheral route can lead to attitude change, as shown in Figure 1.

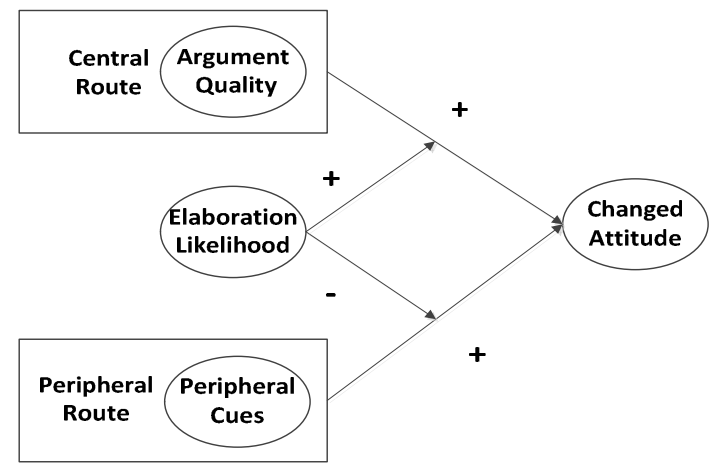

Fig. 1. Elaboration likelihood model

In the context of tourism of this study, source credibility refers to the credibility of website or online community in which eWOM of travel destination is disseminated. Argument quality refers to the quality of content/message contained in the travel destination-related eWOM. Source credibility and argument quality of social media material are empirically tested to be related with attitude formation in the context such as outbound studying destination choice [25] and adoption of accommodation related online review [4]. Thus, we propose that argument quality and source credibility of destination-related eWOM have positive influence on tourists' attitude towards the destination. Hypotheses 1 and 2 are:

H1: Argument quality of destination-related eWOM will positively influence tourists' attitude towards leisure travel destination.

$\mathrm{H} 2$ : Source credibility of destination-related eWOM will positively influence tourists' attitude towards leisure travel destination.

\subsection{Incorporating Behavior Intention to ELM}

Intentions to perform different kinds of behaviors can be predicted from attitude towards the behavior in one of the most researched and reputational psychological theory-theory of planned behavior [20]. Several prior studies applied theory of planned behavior to explore the relationship between tourists' attitude and behavior intention [26-28]. Ajzen (1991) also assumes that a person's likelihood behavior can be dictated to his/her 
available resources. Therefore, we incorporate intention into the elaboration likelihood model. Concretely, the tourists' behavior intention in our study is discussed with the terms of intention to visit a destination and WOM intention. Word-of-Mouth intention refers to tourist intention to recommend a destination to others according to their knowledge gained from destination-related eWOM before their own travel.

Argument quality describes the persuasive strength embedded in the eWOM related to a leisure travel destination. The dependent variables of intention imitated from the theory of planned behavior (TPB) are intention to visit an outbound leisure travel destination, and the intention to recommend the destination (WOM intention). Prior research has focused on predicting WOM adoption from information receiver's perspective [29-31], few researches focused on exploring WOM intention from information sender's perspective [32]. Thus, our research will address the intention to distribute WOM through information sender's perspective based on ELM. Hypotheses 3 to 6 are proposed based on the combination of elaboration likelihood model and theory of planned behavior.

H3: The argument quality of eWOM regarding travel destination will positively influence potential tourist's visit intention.

$\mathrm{H} 4$ : The argument quality of eWOM regarding travel destination will positively influence potential tourist's WOM intention before actual travel behavior.

H5: The source credibility of eWOM regarding travel destination will positively influence potential tourist's WOM intention before actual travel behavior.

H6: The source credibility of eWOM regarding travel destination will positively influence potential tourist's visit intention.

After information searching behavior, an initial destination image will come into formation in the mind of potential tourists [33]. We also propose that positive attitude will lead to word-of-mouth before practical travel experience, and strengthen visit intention.

H7: Tourist's attitude towards destination will positively influence visit intention. tion.

H8: Tourist's attitude towards destination will positively influence WOM inten-

H9: Tourist's WOM intention will positively influence visit intention.

Figure 2 presents the research model and hypotheses in our study:

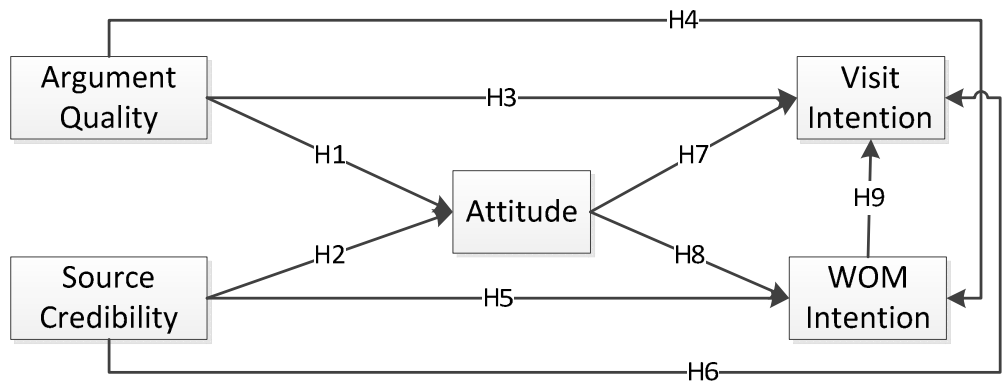

Fig. 2. Research model and hypotheses 


\section{$3 \quad$ Research Method}

\subsection{Data Collection}

Prior to our formal survey in China, pilot studies for both English and Chinese versions of questionnaire have been done during May 5th to 15th 2014. Some Englishspeaking experts and professionals in tourism were interviewed, including academic researchers in University of Turku and the Finnish Tourist Board, to test the logistics, validity, and construct of the questionnaire. The questionnaire was then translated into Chinese after that, and proofread by some bilinguals capable of Chinese and English to ensure the consistence of our questionnaire. The pilot survey of Chinese questionnaire was done among 15 Chinese people to make sure the language and logic of questionnaire in Chinese. The final version was achieved after all the interviews, pilot survey and discussion with experts.

Our data were collected through online survey due to its advantage of faster, cheaper, and easier use for both participants and researchers compared to off-line survey. As our target group is those who are interested in Finland and most potential tourists to Finland in the near future, questionnaire was distributed through the official account of VisitFinland on Wechat and Weibo - two of the most popular social media in China. In this way, potential respondents will mostly be the followers of VisitFinland. As being the followers of official account of Finnish Tourist Board Weibo and Wechat, it's true that they already paid attention to Finland as a travel destination. 959 responses were collected in two weeks after our questionnaire distribution. For our study in this paper, only respondents who have never travelled to Finland, and were influenced by online travel experience or reviews during their destination decision process, were included. Our final samples for analysis consist of 195 respondents.

\subsection{Sample Characteristics}

The demographic profile of our sample is presented in Table 1. More than $80 \%$ are between the age of 20 and 40 years old, and nearly a half of them are singles. Most $(89.7 \%)$ of them received relatively high education from university with a bachelor degree or above. $79 \%$ of them have a monthly income of more than 5,000 Yuan, and more than $40 \%$ of them earn more than 10,000 Yuan per mouth, which confirmed their likelihood of taking an outbound travel in recent three years. In addition, nearly $87 \%$ of the respondents have outbound travel experience in recent three years, and $60 \%$ of them have travelled abroad for at least three times in recent three years.

\subsection{Measurement}

Five factors were included in our model: argument quality, source credibility, attitude towards destination, WOM intention, and visit intention. Each construct was measured with multiple items adapted from previous literatures to validate content. Necessary modifications have been done according to our current research context. 
Table 1. Sample characteristics $(\mathrm{N}=195)$

\begin{tabular}{|c|c|c|c|}
\hline Sample characteristic & Category & Frequency & Percent \% \\
\hline \multirow{2}{*}{ Gender } & Male & 4 & 27.7 \\
\hline & Female & 141 & 72.3 \\
\hline \multirow{5}{*}{ Age } & Less than 20 & 6 & 3.1 \\
\hline & $20-30$ & 94 & 48.2 \\
\hline & $31-40$ & 76 & 39.0 \\
\hline & $41-50$ & 15 & 7.7 \\
\hline & $51-60$ & 4 & 2.1 \\
\hline \multirow{4}{*}{ Education } & Under bachelor degree & 22 & 11.3 \\
\hline & Bachelor degree & 130 & 66.7 \\
\hline & Master degree & 40 & 20.5 \\
\hline & Doctoral degree & 3 & 1.5 \\
\hline \multirow{5}{*}{ Family size } & Single & 95 & 48.7 \\
\hline & Couple without children & 44 & 22.6 \\
\hline & $\begin{array}{l}\text { Couple without children at } \\
\text { home }\end{array}$ & 5 & 2.6 \\
\hline & Couple with children at home & 48 & 24.6 \\
\hline & Other & 3 & 1.5 \\
\hline \multirow{5}{*}{ Income per mouth } & Less than 5,000 & 41 & 21.0 \\
\hline & $5,001-10,000$ & 69 & 35.4 \\
\hline & $10,001-20,000$ & 51 & 26.2 \\
\hline & $20,001-30,000$ & 20 & 10.3 \\
\hline & More than 30,000 & 14 & 7.2 \\
\hline \multirow{5}{*}{$\begin{array}{l}\text { Outbound Travel } \\
\text { Frequency } \\
\text { (in recent three years) }\end{array}$} & 1 & 95 & 13.8 \\
\hline & 2 & 44 & 17.9 \\
\hline & 3 & 5 & 26.2 \\
\hline & 4 & 48 & 8.2 \\
\hline & 5 or more & 3 & 33.8 \\
\hline
\end{tabular}

\section{Data Analysis and Results}

The data were analysed using structural equation model with SPSS Amos 22.0. First, the reliability and validity of the scales used in our measurement model were tested. Model fit was also examined. 


\subsection{Reliability and Validity}

The validation of our measurement model was investigated in both convergent validity and discriminant validity. We investigated convergent validity by computing all factor loadings, composite reliabilities, Cronbach's Alpha and the average variance extracted (AVE). As shown in Table 3, all the factor loadings exceeded the recommended value of 0.70, composite reliabilities exceeded 0.8, and all AVEs exceeded 0.5, which shows a good convergent validity was achieved [34]. All Cronbach's Alpha values are higher than 0.7 , which implies good reliability [35].

Table 2. Convergent validity: Factor loading, composite reliability, Cronbach's Alpha and AVE

\begin{tabular}{|c|c|c|c|c|c|}
\hline Item & $\begin{array}{l}\text { Mean } \\
(N=195)\end{array}$ & $\begin{array}{l}\text { Factor } \\
\text { Loading }\end{array}$ & $\begin{array}{l}\text { Composite } \\
\text { Reliability }\end{array}$ & $\begin{array}{l}\text { Cronbach's } \\
\text { Alpha }\end{array}$ & AVE \\
\hline AQ1 & 4.09 & 0.8867 & \multirow{3}{*}{0.8790} & \multirow{3}{*}{0.7952} & \multirow{3}{*}{0.7081} \\
\hline AQ2 & 3.73 & 0.8151 & & & \\
\hline AQ3 & 3.90 & 0.8208 & & & \\
\hline SC1 & 3.89 & 0.7844 & \multirow{3}{*}{0.8855} & \multirow{3}{*}{0.8591} & \multirow{3}{*}{0.7211} \\
\hline SC2 & 3.84 & 0.8909 & & & \\
\hline SC3 & 3.99 & 0.8686 & & & \\
\hline ATT1 & 4.51 & 0.8828 & \multirow{3}{*}{0.9143} & \multirow{3}{*}{0.8591} & \multirow{3}{*}{0.7809} \\
\hline ATT2 & 4.52 & 0.9361 & & & \\
\hline ATT3 & 4.58 & 0.8289 & & & \\
\hline WOM1 & 4.29 & 0.9356 & \multirow{3}{*}{0.9381} & \multirow{3}{*}{0.9012} & \multirow{3}{*}{0.8349} \\
\hline WOM2 & 4.46 & 0.8730 & & & \\
\hline WOM3 & 4.27 & 0.9313 & & & \\
\hline INT1 & 4.23 & 0.9142 & \multirow{3}{*}{0.9538} & \multirow{3}{*}{0.9273} & \multirow{3}{*}{0.8731} \\
\hline INT2 & 4.35 & 0.9539 & & & \\
\hline INT3 & 4.45 & 0.9346 & & & \\
\hline
\end{tabular}

In addition, we compared the square root of the AVE and factor correlation coefficients to examine the discriminant validity of our constructs. As shown in Table 4 below, all factors' latent variable correlations with other factors are smaller than the square root of its AVEs, which shows a good discriminant validity of our scales [34, 36].

Table 3. Discriminant validity: latent variable correlations and the square roots of AVEs (Square root of AVEs in the main diagonal)

\begin{tabular}{|l|l|l|l|l|l|}
\hline & AQ & SC & ATT & WOM & INT \\
\hline AQ & $\mathbf{0 . 8 4 1 5}$ & & & & \\
\hline SC & 0.5987 & $\mathbf{0 . 8 4 9 2}$ & & & \\
\hline ATT & 0.1750 & 0.1480 & $\mathbf{0 . 8 8 3 7}$ & & \\
\hline WOM & 0.1281 & 0.1768 & 0.6563 & $\mathbf{0 . 9 1 3 7}$ & \\
\hline INT & 0.2400 & 0.1525 & 0.5903 & 0.6747 & $\mathbf{0 . 9 3 4 4}$ \\
\hline
\end{tabular}




\subsection{Hypotheses Testing}

Before exploring the path coefficient, the goodness of model fit was tested in AMOS. The results of model fit were shown in Table 5. According to the rules of thumb, the values of GFI, NFI,CFI all proved a satisfactory structural model fit to the data [37].

Table 4. Goodness-of-fit measures for original model

\begin{tabular}{|c|c|c|c|c|}
\hline Chi-square & Degrees of freedom & GFI & NFI & CFI \\
\hline $199.890(.000)$ & 81 & 0.891 & 0.853 & 0.937 \\
\hline
\end{tabular}

Notes: $p$-value in parentheses; GFI=goodness of fit; NFI=normal fit index; $\mathrm{CFI}=$ comparative fit index.

Figure 3 graphically presents our path coefficient results and variance explained. Six out of nine hypotheses were supported in our results (see Table 6). The results indicate that: tourist's attitude towards destination was positively influenced by argument quality $(\beta=0.173, p<0.01)$; word-of-mouth intention was positively influenced by attitude $(\beta=0.720, \mathrm{p}<0.001)$ and source credibility $(\beta=0.104, \mathrm{p}<0.01)$; visit intention was positively influenced by argument quality $(\beta=0.192, \mathrm{p}<0.01)$, attitude towards destination $(\beta=0.149, p<0.05)$, and WOM intention $(\beta=0.620, p<0.001)$. It is estimated that predictors in our model of visit intention can explain 58.5 percent of its variance, 52.7 percent of WOM intention, and 3.5 percent of attitude.

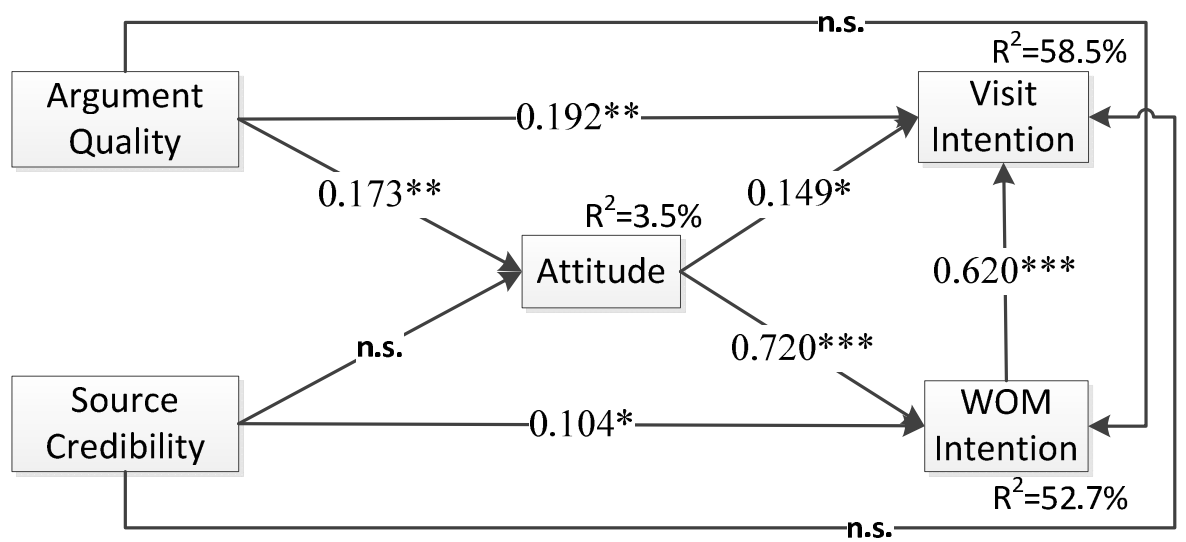

Note: n.s.: not significant; ${ }^{* * *} \mathrm{p}<0.001 ;{ }^{*} \mathrm{p}<0.01 ;{ }^{*} \mathrm{p}<0.05$

Fig. 3. Results of analysis 
Table 5. Summary of hypotheses testing

\begin{tabular}{|l|l|}
\hline Hypothesis & \multicolumn{1}{|l|}{ Result } \\
\hline H1: Argument quality $\rightarrow$ Attitude towards destination $(+)$ & Supported \\
\hline H2: Source credibility $\rightarrow$ Attitude towards destination $(+)$ & Not Supported \\
\hline H3: Argument quality $\rightarrow$ Visit intention $(+)$ & Supported \\
\hline H4: Argument quality $\rightarrow$ WOM intention $(+)$ & Not Supported \\
\hline H5: Source credibility $\rightarrow$ WOM intention $(+)$ & Supported \\
\hline H6: Source credibility $\rightarrow$ Visit intention $(+)$ & Not Supported \\
\hline H7: Attitude $\rightarrow$ Visit intention $(+)$ & Supported \\
\hline H8: Attitude $\rightarrow$ WOM intention $(+)$ & Supported \\
\hline H9 WOM intention $\rightarrow$ Visit intention $(+)$ & Supported \\
\hline
\end{tabular}

\section{Conclusions and Discussion}

\subsection{Main Results}

The results of this study demonstrate a combination of dual process attitude change theory-elaboration likelihood model-with the theory of planned behavior. The empirical results indicate that tourist's attitude towards travel destination is positively influenced by argument quality rather than source credibility of eWOM. However, argument quality of eWOM will only influence tourists' own attitude and visit intention, but not their recommendation behavior. Additionally, it's not argument quality but source credibility of eWOM that would lead to tourist's recommendation intention even before their own travel experience. Contrarily, tourist's visit intention is influenced by eWOM through a central route of argument quality, but the influence of source credibility is not significant as implicated by our empirical results. Consistent with prior research results, visit intention and recommendation intention were positively influenced by attitude [38].

\subsection{Practical Implications}

This research contributed to tourism industry for giving implications on better understanding tourists' decision making behavior. As an information intensive industry, nowadays increasing amount of new information and communication technology (ICT) has been penetrating into nearly every tourism sector [39]. As to tourism stakeholders, especially for destination marketers, this study makes great value in their understanding of what types of information positively motivate potential tourist attitude towards destination, and finally visit intention.

Our empirical findings also indicated that during tourist's destination decision making process, argument quality of online information sources is highly valued for the formation of positive initial image and attitude towards travel destination. It means that, in tourist's destination decision making process, tourist will think critically about destination-related arguments and scrutinize the relative merits and relevance of those arguments prior to forming a positive attitude to travel destination, and 
further visit intention. In this case, eWOM will influence tourist's destination decision through a central route.

However, tourist's recommendation behavior was influenced by source credibility and attitude towards destination rather than argument quality. It implies that individuals' recommendation behavior is determined more by the credibility of the source they obtained, but requires less scrutinize of the information and content contained in the eWOM itself. Thus, eWOM will influence tourist's recommendation behavior through a peripheral route, which is cues-oriented.

\subsection{Theoretical Implications}

This research also has theoretical implications in IS user behavior research. As illustrated, our research model synthesized the dual-process theory and the theory of planned behavior in social psychology literature by incorporating behavior intention into ELM. The model was empirically tested in the context of electronic word-ofmouth in tourism. These two models complete each other. Theory of planned behavior illustrates the relationship between attitude and intention, but does not explain the how the influence process before attitude formation. Elaboration likelihood model supplement TPB in the influence process before the very initial attitude change. The combination of these two models shows good model fitness with our data. Thus, our research contributes a predictive model of influence process of IS on user's intention in the context of tourism.

\section{$6 \quad$ Limitation and Future Research}

Some limitations exist in this research. Exploring outbound tourist behavior is challenging, especially for an empirical research not only due to the difficulties in data collection, but also in the uncertainty influence of multi-culture values. Thus, data collection could conduct through wider channels in future study. In addition, the impact of culture values should be taken into consideration in future research.

We explored potential tourist's visit intention through a general dual influence process perspective, which limits the explanation power of attitude in our model. Therefore, research in the future could decompose attributes of argument quality of eWOM to identify the decomposed attribute of argument quality.

Acknowledgement. I would like to state my gratitude to Katarina Wakonen and Kristiina Hietasaari in Finnish Tourist Board and VisitFinland representatives in China for the data collection, the participants for pilot study, as well as Hongxiu Li, Reima Suomi for all the assistance in conducting this study.

This research is supported by China Scholarship Council, and part of the achievements of the China MOE Project of Humanities and Social Sciences (No.13YJC630228), and the National Natural Science Foundation of China (No. 71362027). 


\section{References}

1. Kim, M.J., Lee, C.K., Chung, N., Kim, W.G.: Factors Affecting Online Tourism Group Buying and the Moderating Role of Loyalty. Journal of Travel Research 53(3), 380-394 (2014)

2. Bronner, F., de Hoog, R.: Vacationers and eWOM: Who Posts, and Why, Where, and What? Journal of Travel Research 50(1), 15-26 (2011)

3. Shih, H.P., Lai, K.H., Cheng, T.C.E.: Informational and Relational Influences on Electronic Word of Mouth: An Empirical Study of an Online Consumer Discussion Forum. International Journal of Electronic Commerce 17(4), 137-165 (2013)

4. Filieri, R., McLeay, F.: E-WOM and Accommodation: An Analysis of the Factors That Influence Travelers' Adoption of Information from Online Reviews. Journal of Travel Research 53(1), 44-57 (2014)

5. Kozak, M.: Holiday taking decisions - The role of spouses. Tourism Management 31(4), 489-494 (2010)

6. Jalilvand, M.R., Samiei, N.: The impact of electronic word of mouth on a tourism destination choice Testing the theory of planned behavior (TPB). Internet Research 22(5), 591-612 (2012)

7. Li, H., Yong, L.: Post adoption behaviour of e-service users: an empirical study on Chinese online travel service users. In: ECIS 2011 Proceedings, Paper 56 (2011)

8. Cox, C., Burgess, S., Sellitto, C., Buultjens, J.: The role of user-generated content in tourists' travel planning behavior. Journal of Hospitality Marketing \& Management 18(8), 743-764 (2009)

9. Li, H., Liu, Y.: Understanding post-adoption behaviors of e-service users in the context of online travel services. Information \& Management (2014)

10. Tham, A., Croy, G., Mair, J.: Social Media in Destination Choice: Distinctive Electronic Word-of-Mouth Dimensions. Journal of Travel \& Tourism Marketing 30(1-2), 144-155 (2013)

11. Standing, C., Tang-Taye, J.P., Boyer, M.: The Impact of the Internet in Travel and Tourism: A Research Review 2001-2010. Journal of Travel \& Tourism Marketing 31(1), 82-113 (2014)

12. Amaro, S., Duarte, P.: Online Travel Purchasing: A Literature Review. Journal of Travel \& Tourism Marketing 30(8), 755-785 (2013)

13. Cantallops, A.S., Salvi, F.: New consumer behavior: A review of research on eWOM and hotels. International Journal of Hospitality Management 36, 41-51 (2014)

14. Litvin, S.W., Ronald, E.: Goldsmith, and Bing Pan, Electronic word-of-mouth in hospitality and tourism management. Tourism Management 29(3), 458-468 (2008)

15. Iang, J.X., Gretzel, U., Law, R.: Do Negative Experiences Always Lead to Dissatisfaction? - Testing Attribution Theory in the Context of Online Travel Reviews. Information and Communication Technologies in Tourism 297-308 (2010)

16. Jeong, E., Jang, S.: Restaurant experiences triggering positive electronic word-of-mouth (eWOM) motivations. International Journal of Hospitality Management 30(2), 356-366 (2011)

17. Munar, A.M., Jacobsen, J.K.S.: Motivations for sharing tourism experiences through social media. Tourism Management 43, 46-54 (2014)

18. Cheung, C.M.K., Lee, M.K.O., Rabjohn, N.: The impact of electronic word-of-mouth The adoption of online opinions in online customer communities. Internet Research 18(3), 229-247 (2008) 
19. Verhagen, T., Nauta, A., Feldberg, F.: Negative online word-of-mouth: Behavioral indicator or emotional release? Computers in Human Behavior 29(4), 1430-1440 (2013)

20. Ajzen, I.: The theory of planned behavior. Organizational Behavior and Human Decision Processes (50), 179-211 (1991)

21. Ajzen, I.: Nature and operation of attitudes. Annual Review of Psychology 52, 27-58 (2001)

22. Petty, R.E., Cacioppo, J.T., Schumann, D.: Central and peripheral routes to advertising effectiveness: The moderating role of involvement. Journal of Consumer Research 10(2), 135 (1983)

23. Bhattacherjee, A., Sanford, C.: Influence processes for information technology acceptance: An elaboration likelihood model. MIS Quarterly 30(4), 805-825 (2006)

24. Priester, J.R., Petty, R.E.: The influence of spokesperson trustworthiness on message elaboration, attitude strength, and advertising effectiveness. Journal of Consumer Psychology 13(4), 408-421 (2003)

25. Shu, M., Scott, N.: Influence of Social Media on Chinese Students' Choice of An Overseas Study Destination: An Information Adoption Model Perspective. Journal of Travel \& Tourism Marketing 31(2), 286-302 (2014)

26. Lam, T., Hsu, C.H.C.: Predicting behavioral intention of choosing a travel destination. Tourism Management 27(4), 589-599 (2006)

27. Hsu, C.H.C., Huang, S.: An Extension of the Theory of Planned Behavior Model for Tourists. Journal of Hospitality \& Tourism Research 36(3), 390-417 (2012)

28. Song, H., You, G.-J., Reisinger, Y., Lee, C.-K., Lee, S.-K.: Behavioral intention of visitors to an Oriental medicine festival: An extended model of goal directed behavior. Tourism Management 42, 101-113 (2014)

29. Cheung, M.Y., Luo, C., Sia, C.L., Chen, H.P.: Credibility of Electronic Word-of-Mouth: Informational and Normative Determinants of On-line Consumer Recommendations. International Journal of Electronic Commerce 13(4), 9-38 (2009)

30. Jin, S.A.A., Phua, J.: Following Celebrities' Tweets About Brands: The Impact of TwitterBased Electronic Word-of-Mouth on Consumers' Source Credibility Perception, Buying Intention, and Social Identification With Celebrities. Journal of Advertising 43(2), 181-195 (2014)

31. Fang, Y.H.: Beyond the Credibility of Electronic Word of Mouth: Exploring eWOM Adoption on Social Networking Sites from Affective and Curiosity Perspectives. International Journal of Electronic Commerce 18(3), 67-101 (2014)

32. Shih, H.-P., Lai, K.-H., Cheng, T.C.E.: Informational and Relational Influences on Electronic Word of Mouth: An Empirical Study of an Online Consumer Discussion Forum. International Journal of Electronic Commerce 17(4), 137-165 (2013)

33. Fodness, D., Murray, B.: Tourist information search. Annals of Tourism Research 24(3), 503-523 (1997)

34. Fornell, C., Larcker, D.F.: Structural equation models with unobservable variables and measurement error: Algebra and statistics. Journal of Marketing Research, 382-388 (1981)

35. Nunnally, J.C., Ira, H.: Bernstein, and Jos MF ten Berge, Psychometric theory, vol. 226. McGraw-Hill, New York (1967)

36. Haas, J.S., Kaplan, C.P., Gerstenberger, E.P., Karlikowske, K.: Changes in the Use of Postmenopausal Hormone Therapy after the Publication of Clinical Trial Results. Ann. Intern. Med. 140, 184-188 (2004) 
37. Gefen, D., Straub, D., Boudreau, M.-C.: Structural equation modeling and regression: Guidelines for research practice. Communications of the Association for Information Systems 4(1), 7 (2000)

38. Wang, J., Ritchie, B.W.: Understanding accommodation managers' crisis planning intention: An application of the theory of planned behaviour. Tourism Management 33(5), 1057-1067 (2012)

39. Zelenka, J.: Information and Communication Technologies in Tourism - Influence, Dynamics, Trends. E \& M Ekonomie a Management 12(1), 123-132 (2009) 